\title{
Do you really want to be a biotech board member?
}

\author{
Mark Kessel \\ There are many advantages to becoming a company advisor, but academics should think carefully about the legal and \\ personal implications before accepting a seat on the board.
}

\begin{abstract}
$\Delta$ t some time in your career, your expertise Amay be essential for a biotech company with a program in your field of translational research. There are many ways in which you may interact with a company: informal consultations, invitations to speak to company R\&D leaders on site, formal invitations to serve on a scientific advisory board $(\mathrm{SAB})$ or recruitment to a company's board of directors. You should understand that each of these interactions with industry has different legal and fiduciary responsibilities. In this article, I outline some of the most important aspects for you to bear in mind if you are invited to join a company's board in the United States.
\end{abstract}

\section{Welcome to the board}

A crucial aspect for any academic working on important translational research problems is outreach to colleagues in industry, who can provide feedback on the types of issues companies feel are most important in taking research discoveries forward in development. Informal interactions and dialogue is how this starts. Short consultancies may follow. Finally, you may be asked to serve on a company's SAB. The last role involves acting as an advisor on specific scientific or clinical matters for which the biotech company needs advice; the time commitment is generally limited to attending a meeting annually or semiannually as needed and getting compensated on a per diem basis. All of these interactions with companies do not expose you to potential liability, whether financial or reputational.

But there is another role that involves a more direct connection with a company: serving as a director of a public company. In this case, you will receive equity and cash compensation, and your role is acting as a fiduciary to the public shareholders, with a substantially greater time

Mark Kessel is of counsel at Shearman \& Sterling LLP, New York, New York, USA. e-mail:mark.kessel@shearman.com.

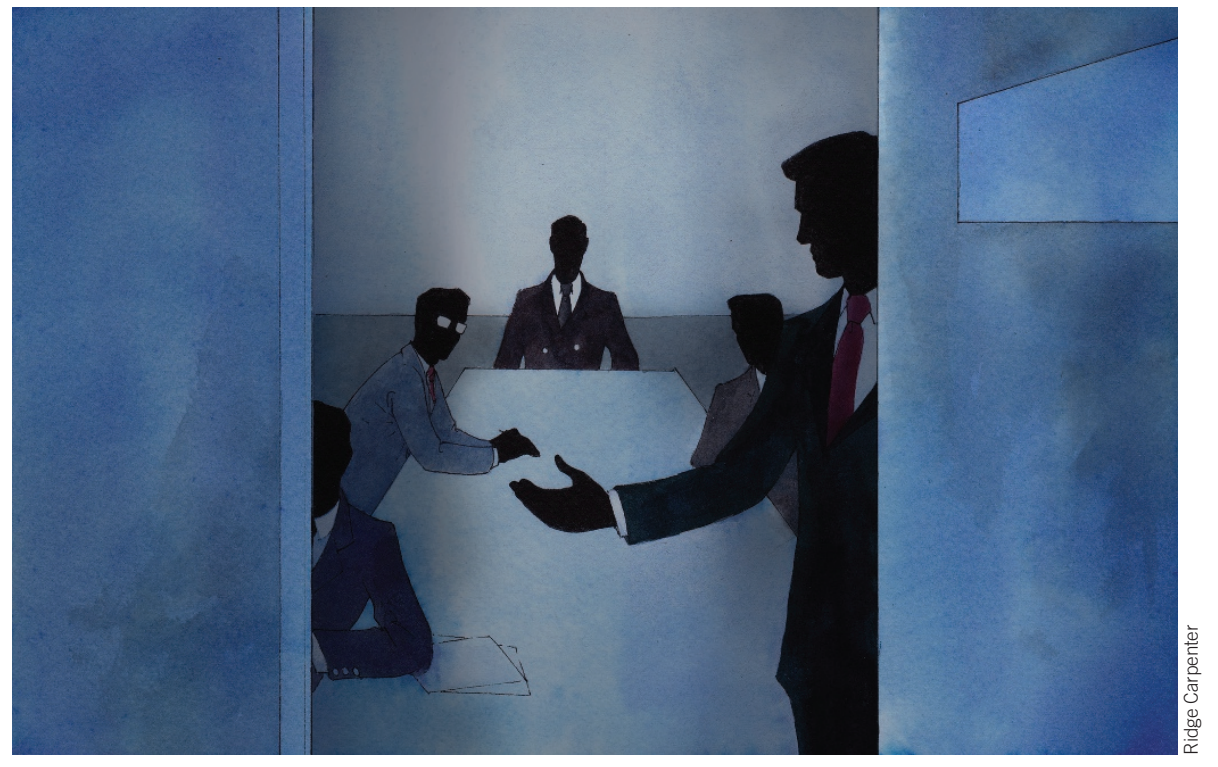

There's plenty to consider before walking through that door.

commitment and more legal and reputational exposure. Therefore, you need to better appreciate not only what you are getting yourself into but also how to ensure that you are doing the appropriate diligence to assure yourself that this is the right company and role for you.

Unlike being a member of a $\mathrm{SAB}$, in the corporate world your appointment as an independent director means you are now part of the bedrock for the proper functioning of a company's board of directors. You are being hired to bring necessary expertise, independent judgment and act as a reality check on the strategy and vision for the company espoused by the CEO. At the same time, you need to be aware that in many organizations the real power resides with the CEO; often the board of directors is sidelined and their potential contribution unrealized.

If you are asked to join a biotech company's board of directors, you need to carefully assess what kind of board you are joining - one dominated by the CEO or one in which the CEO acknowledges the legal responsibility of the board and welcomes independently minded directors. Alternatively, you may be faced by a board controlled by venture capitalists or other shareholders whose business objectives may be at odds with the founders or public shareholders on critical issues, such as raising additional equity with the attendant stock dilution or a premature sale of the company. These distinctions are not without consequences, as by serving on a board you will be exposing yourself to potential liability and putting your assets and reputation at risk. So how do you go about discerning what you might be getting yourself into?

\section{The investor climate today}

You should understand that your appointment as a company director today comes with substantially more onerous responsibilities than it 
would have in the past. As investors demand more accountability and more effective corporate governance, they are continuing to get a sympathetic response from regulators-the US Securities and Exchange Commission (SEC), the New York Stock Exchange and NASDAQ, based in Washington, DC. They have imposed ever-increasing responsibilities on listed companies and company directors to foster good governance. These include, among many others: regulating the composition of audit, compensation and governance committees; and requiring companies to adopt and publish on their websites a code of business ethics and conduct, disclose board attendance records and hold executive sessions of independent directors. In addition, proxy advisory firms, such as ISS in Rockville, Maryland, and Glass Lewis in San Francisco, monitor governance practices at biotech companies and advise their shareholders on how to cast ballots on matters submitted for a vote.

It is apparent that the financial meltdown of 2008 has resulted in investors clamoring for additional legal, regulatory and structural changes to address boardroom underperformance. Thus, you should expect that with the passage of time, your burden as an outside director is going to become even more demanding.

\section{What you need to know at the outset}

One way of considering the pros and cons of an offer to sit on a board is to think about the legal responsibilities such a position brings. Another way is to look at the kinds of risk to your personal and academic reputation you might encounter when taking such a role. Although the corporate fiduciary responsibilities you face as a director of a private company do not differ in any meaningful way from those of a public company director (discussed below), the legal responsibilities you need to fulfill greatly increase when the company is regulated by the SEC and the stock exchange. Bear in mind that even if you are asked to join the board of a private company, it is likely the company will want to avail itself of public equity markets and that you will be expected to continue in your role as a director.

Your exposure to liability. A seat on the board of a publicly traded biotech company comes with several potential personal liabilities. In brief, most biotech companies in the United States are organized under the laws of the state of Delaware, which impose fiduciary duties on the board of directors. Under the corporate laws of Delaware, directors are charged with the fiduciary duty to protect the interests of the company and act in the best interests of its stockholders. Specifically, directors owe the company the following fiduciary duties: care, loyalty and good faith. With respect to each of these duties, Delaware courts will ordinarily defer to business decisions made by a board of directors under the business judgment rule. This rule is a presumption that the directors acted on an informed basis, in good faith and in the honest belief that their action was in the company's best interests. Under the business judgment rule, absent fraud, self-dealing or abuse of discretion, and if the directors have exercised due care in making an informed judgment, directors' decisions relating to business matters that are attributable to a rational business purpose generally will be sustained as a proper exercise of their discretion. Directors with specialized knowledge or expertise (e.g., as those qualified to serve on an audit committee of a board) may be subject to a higher standard of care depending on the facts and circumstances. In addition, the securities laws of the United States subject directors to potential liability, both civil and criminal, for material misstatements or omissions contained in filings with the SEC.

As a result of these sources of liability, US lawyers tend to institute lawsuits against biotech companies and their directors after stock prices have dropped precipitously as a result of some event(s), even when the cause was totally out of the control of the company, such as an adverse decision from the US Food and Drug Administration (FDA) or one of its advisory panels. Although these suits generally get settled and insurance policies or the companies cover your legal fees or potential damages, you may have to reach into your own pockets to satisfy the asserted claims.

For all practical purposes, if you are offered a seat on the board of a foreign public company, you will find that your responsibilities as a director should not be dissimilar from those for a US public company. In any case, it is common practice for the company to provide you with a memorandum prepared by its counsel summarizing your responsibilities and potential liabilities as a director.

Your reputational exposure. Even if you walk away without having to pay any monetary damages, you may still become embroiled in a stockholder lawsuit. These can go on for years and are often accompanied by publicity and assertions that the board of directors, yourself included, committed securities fraud or breach of fiduciary duties. This is not the type of publicity that your academic institution or your colleagues at that institution may welcome. If you are on the board of another company, that company's management, board of directors or shareholders may also take an unkind view of your entanglement with litigation.

\section{Doing your diligence}

When you make a major purchase, you probably do your homework. Thus, it is surprising how many individuals fail to do their diligence when asked to join a board-a decision that can impact both wallet and reputation. Consider some basic steps that you should take before accepting that plush seat in the boardroom.

Public filings. Start with the company's public filings and see how it is faring from a financial and business point of view. In the United States, these filing can easily be accessed through the SEC website (http://www.sec.gov/) by typing the company's name on the EDGAR link. The principal documents you will want to study are the annual report on form $10-\mathrm{K}$ and the proxy statement. These filings will give you a wealth of information, including the company's business, financials, regulatory matters, litigation and background information on its officers and directors. Securities regulators in other countries have websites that will give you similar information.

As you review these and other filings, you need to assess whether you might be taking on more than you bargained for. On the financial front, some examples of items of concern, depending on the size of the biotech company, are: signs of weakening in the company's financial condition, actual results not meeting securities analyst expectations, unexpected year-end transactions that resulted in substantial revenues, and changes in independent auditors that resulted from accounting disagreements. On the business side, examples include: unexpected resignations or replacements of key personnel; lawsuits filed against the company, such as patent infringement or licensing disputes; overly optimistic press releases or shareholder communications related to the company's drug pipeline or its clinical trials; and a poor relationship with regulators. These items should be discussed with management and the relevant outside advisors to discern their gravity.

Interview, interview, interview. Once you have familiarized yourself with the company's business and believe you can make a meaningful contribution to the board based upon your own background, start to meet the people who will matter: the CEO, key management, board members and outside advisors.

Spend time with the CEO and determine whether he welcomes individuals on the board who are independently minded with a range of business and leadership experience and who would put in the time to become familiar with the company. Does the CEO understand the role of the board? Test the CEO's credibility by reviewing the credentials of the current members of the 
board. Have board members been selected for their 'star power'? Are they respected individuals with the requisite background? Have they perhaps been selected instead on the basis of friendship (i.e., individuals who will let the CEO run the company without interference)? Are any board members nominees of venture capital or other firms that have a large investment in the company with their own agenda? This is important to know as those individuals may control the board in such a way that they interfere with your responsibilities to the public shareholders as a whole.

You also need to make sure that the CEO is really interested in the board of directors being a resource to make better strategic decisions. In this regard, does the $\mathrm{CEO}$ provide the board with the information that it needs to make the important decisions early enough so it can analyze and be ready to weigh in on the topic at a board meeting? A key factor is to determine whether the board plays an active role in the company's strategic direction. Does the CEO give the board access to key management, legal counsel, auditors and other outside advisors? Aside from your meetings or conversations with the chairman of the board or the lead director, as well as other board members and management, you should ask to talk to these outside advisors to get their perspective on the company and discern whether there are any major issues lurking in the background that the CEO or management has not disclosed to you. For a board to function effectively, it needs to be cohesive enough to fulfill its legal obligations, including removing a CEO not up to the task. Thus, the personalities of the other board members cannot be ignored. A director who does not know how to play in the board sandbox can be a very disruptive element to board effectiveness.

Putting in the time. Most public biotech boards have about six to eight independent directors. In addition to the regular board meetings, you can also expect to serve on one or more of the audit, compensation and governance committees (all of which are mandated by the regulators). In general, the board will need to meet a minimum of four times a year, and the committee meetings generally are set up around the same dates. However, special situations can easily involve more board time-financings, major business transactions or litigation are some situations commonly encountered. In the case of a major conflagration, you could be tied up in endless crisis meetings. Thus, you need to be certain that you will be able to put in the time to prepare for the meetings and actually attend them and that your academic or other employer is not opposed to you devoting this amount of time to an outside activity. There is a legal requirement for companies to disclose board attendance and list directors who have attended less than $75 \%$ of the board and committee meetings. This is not insignificant to a company as ISS and Glass Lewis may recommend a vote against directors with poor attendance records.

\section{Conclusions}

Biotech companies, recognizing the importance of the board to investors, are in constant need of qualified directors, especially those who have the requisite background to fulfill the legal requirements necessary to serve on audit committees. The composition of the board is often looked upon by investors as a key ingredient in their determination as to whether to buy, hold or sell the stock of the company. Investors often divest their holdings if they discern a lapse in corporate governance with the concomitant adverse impact on the stock price. As prospective directors are exposing themselves to potential liability and reputational risk and are expected to put in the time to do their job, the pool of qualified directors for biotech companies who are inclined to join a board is not plentiful. Many are called but not all respond.

If you are invited to join a board, you need to do your diligence and, in the end, be assured that the CEO is really looking to team up with the board and there is a true, appropriate balance of power between the two. Also, you should be convinced that other directors do not call all the shots so as to preclude your voice from being heard. However, this does not mean that directors responding to pressure from investors should micromanage the company and hamstring the CEO. But it does mean that all the power does not reside with the CEO or any single director or subset of directors.

\section{Startups on the menu}

In 2012, Salvatore Albani, then at the Sanford-Burnham Medical

Research Institute in La Jolla, California, presented at SciCafé his work exploiting the role of heat shock protein (HSP) in rheumatoid arthritis. Albani has developed a 15-mer synthetic peptide, dnaJP1, derived from HSP dnaJ. Oral administration of the peptide, which is one of the dominant proinflammatory epitopes in rheumatoid arthritis, is thought to induce mucosal tolerance and suppress inflammation. A company formed around the intellectual property, Archimedes Therapeutics, took the peptide into a proof-of-concept phase $2 \mathrm{a}$ trial in rheumatoid arthritis (E.C. Koffeman et al., Arthritis Rheum. 60, $3207-3216,2009$ ) and is now seeking funds to support a phase 3 trial. Nature Biotechnology talked to Albani about his involvement in Archimedes.

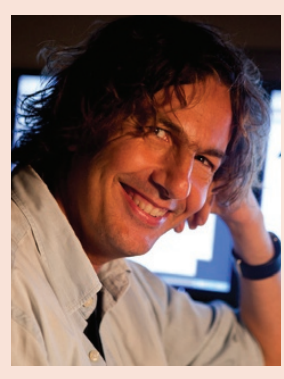
Nature Biotechnology: When did you decide to start a company?

Salvatore Albani: The idea was the outcome of discussions with friends and colleagues who became excited by the opportunity to do something novel. Targeting the HSP proinflammatory circuit, rather than the initial antigen triggering disease, was a completely new approach to arthritis treatment; there is also a need for an alternative to current biologic treatments against tumor necrosis factor-a, which mediate nonspecific
SA: In addition to dnaJP1, we have a biomarker platform that addresses a large unmet medical need-the inability to predict responsiveness to expensive therapies that work only in a proportion of RA patients. The development of this biomarker technology into a chip to be used to inform therapeutic decisions is potentially attractive for the patients, first and foremost, but also for the payers and for industry, which is jockeying for market share in a crowded space. This technology has been

immunosuppression and are associated with serious adverse toxicities. A group of professionals with complementary experiences and expertise formed Archimedes Therapeutics with the objective to raise sufficient capital to support clinical development. Seed funding was provided by some of the company's partners.

\section{NBT: What are your future plans for Archimedes?} acquired by another company and licensed for co-development.

\section{NBT: How do you balance your academic and entrepreneurial roles?}

SA: At Archimedes I provide information and advice for scientific development of the product. There is no intersection at this time with anything I do in academia, and I go to great lengths to ensure that my roles are well demarcated. 